\title{
Margaret McCartney: If you don't pay for it you are the product
}

\author{
Margaret McCartney general practitioner
}

Glasgow

When I search for "cow's milk protein allergy" the first website to come up is Allergy UK. The first page has an offer for "a new masterclass for GPs in 2018!"' It's free, but it's sponsored by Nutricia, which makes formula milk.

Elsewhere on the Allergy UK website parents are offered information relating to "delayed Cow's Milk Allergy," in the form of "What symptoms should I look out for?"-and I wonder how many babies have not had any of the eczema/diarrhoea/colic/constipation/not feeding/reflux/vomiting symptoms listed. As there are "no tests for delayed Cow's Milk Allergy," the website continues, if you're formula feeding "your GP will need to switch your infant over to a prescribed formula," such as one of the ones Nutricia makes.

It's 2018, and we're surely all getting tired of the charade that people are immune to advertising. Surely, it should be clear: don't take education from people who tell you that you're not using enough of the stuff they sell.

This shouldn't be difficult. It should be easy for us to obtain high quality, independent education. After all, there are several companies operated by GPs that do precisely this while rejecting all advertising. Yet the National Institute for Health and Care Excellence still allows committee members to accept lecture and consulting fees from industry while continuing to participate in "discussions on all topics." 3

Beliefs persist that we're not influenced by advertising and that sponsored education can be received free, without adverse consequence. But if we don't pay for the product, dear colleagues-we are the product. When we sit in the grey area between underdiagnosis and overdiagnosis, as we usually do, we need to ask hard questions about how sure we can be that what we're being taught, or where we're being directed, is actually right. We're all subject to biases: even small gifts or nudges can change our behaviours. ${ }^{4}$

Beliefs persist that we're not influenced by advertising and that sponsored education can be received free, without adverse consequence
Last year a group called the Anaemia Manifesto visited parliament. Its public relations team noted that the research agency GK Strategy had organised a summit "to consider why North, East and West Devon has the highest rates of iron deficiency anaemia hospital admissions in the country, and to discuss solutions."

The Anaemia Manifesto offered a "free anaemia test" to MPs, staff, and journalists in Westminster. The same group has also written to the Public Accounts Committee to say that iron deficiency anaemia "remains under-diagnosed and under-treated" and to warn about "suboptimal use of appropriate therapies." The group was created through an "unrestricted educational grant" from Vifor Pharma. ${ }^{5}$ But the invitation to MPs did not state this.

The chair of the Anaemia Manifesto ${ }^{7}$ is a non-executive director of a company that seeks to "further develop market access strategies and partnership working between our pharma clients, the new Clinical Commissioning Groups, providers, regulators and patients." 8 One of the directors is a consultant to "a number" of pharmaceutical and device manufacturers. ${ }^{8}$ Another is the director of a clinic that manages iron deficiency anaemia who has received "grant, personal fees and non-financial support" from Vifor. ${ }^{9}$

Doctors should seek independent education. In fact, we should all do so-including MPs, guideline committees, patients, and the public.

Competing interests: See www.bmj.com/about-bmj/freelance-contributors/margaretmccartney.

Provenance and peer review: Commissioned; not externally peer reviewed.

Allergy UK. https://www.allergyuk.org/.

2 Allergy UK. Could it be Cow's Milk Allergy? July 2017. https://www.allergyuk.org/assets/ 000/000/791/CMA_6_Page_original.pdf?1501583691.

3 National Institute for Health and Care Excellence. Declarations of interest: food allergy in children. https://www.nice.org.uk/guidance/cg116/evidence/full-guideline-appendix-4declarations-of-interest-pdf-136470065.

4 Fineberg HV. Conflict of interest: why does it matter? JAMA 2017;317:1717-8. https:// jamanetwork.com/journals/jama/article-abstract/2623615. 10.1001/jama.2017.1869 28464149

5 GK Strategy. Client: Vifor Pharma UK. https://gkstrategy.com/client-vifor-pharma-uk/. 
6 Written evidence submitted by Anaemia Manifesto Steering Committee. 9 April 2018 http://data.parliament.uk/writtenevidence/committeeevidence.svc/evidencedocument/ public-accounts-committee/avoiding-unnecessary-emergency-admissions/written/81900. html.

7 Anaemia Manifesto. The Anaemia Manifesto Steering Committee: committee member declaration. 2018. https://anaemiamanifesto.com/committee-members/.

8 Michael Sobanja joins medical management services (UK) Ltd as non executive director. www.medman.co.uk/news.
9 Chau M, Richards T, Evans C, Butcher A, Collier T, Klein A. The UK Cardiac and Vascular Surgery Interventional Anaemia Response (CAVIAR) Study: protocol for an observational cohort study to determine the impact and effect of preoperative anaemia management in cardiac and vascular surgical patients. BMJ Open 2017;7:e014872. https://bmjopen.bmj. com/content/bmjopen/7/4/e014872.full.pdf. 10.1136/bmjopen-2016-014872 28420664

Published by the BMJ Publishing Group Limited. For permission to use (where not already granted under a licence) please go to http://group.bmj.com/group/rights-licensing/ permissions 